\title{
Mentőtiszthallgatók felnőtt emelt szintü újraélesztéssel kapcsolatos ismeretei Magyarországon
}

\author{
Bánfai Bálint ${ }^{1}$ - Éliás Ádám ${ }^{3}$ - Nagy Tamás ${ }^{4}$ \\ Pék Emese ${ }^{1}$ - Betlehem József dr. ${ }^{2}$ \\ Pécsi Tudományegyetem, ${ }^{1}$ Egészségtudományi Kar, Sürgősségi Ellátási és Egészségpedagógiai Intézet, \\ ${ }^{2}$ Egészségtudományi Kar, Pécs \\ ${ }^{3}$ Országos Mentőszolgálat, Nyugat-dunántúli Régió, Csornai Mentőállomása, Csorna \\ ${ }^{4}$ Országos Mentőszolgálat, Nyugat-dunántúli Régió Szentgotthárdi Mentőállomása, Szentgotthárd
}

\begin{abstract}
Bevezetés: A megfelelő emelt szintű újraélesztési ismeretek elengedhetetlenek a sürgősségi ellátásban dolgozó szakemberek számára. Célkitüzés: A szerzôk célja a magyarországi mentőtiszthallgatók felnőtt emelt szintü újraélesztési ismereteinek felmérése volt. Módszer: Felmérésüket a Pécsi Tudományegyetem Egészségtudományi Karának, a Semmelweis Egyetem Egészségtudományi Karának és a Debreceni Egyetem Egészségügyi Karának III. és IV. évfolyamos hallgatói körében végezték, saját szerkesztésủ kérdőív segítségével. A mintába 97 fő hallgató került be $(\mathrm{n}=97)$. Eredmények: A hallgatók átlagosan 67,79\%-os eredménnyel teljesítettek a felmérésen. A férfiak és a nők összpontszámai között nem volt szignifikáns különbség $(\mathrm{p}=0,725)$. Az alacsony életkor szignifikánsan javította az elért összpontszámokat $(\mathrm{p}=0,003)$. A nappali tagozatosok szignifikánsan magasabb összpontszámot értek el, mint a levelezősök $(\mathrm{p}=0,004)$. Az egyes képzőintézmények hallgatóinak összpontszámai között szignifikáns különbség nem volt a felmérés során $(\mathrm{p}=0,254)$. Következtetések: Célszerü lenne a mentőtisztképzésben a témával foglalkozó tantárgyak számát növelni, a számonkérések kritériumrendszerét szigorítani. A szerzők a jövőben indokoltnak tartanák a gyakorlati ismereteket vizsgáló felmérés elvégzését. Orv. Hetil., 2016, 157(37), 1476-1482.
\end{abstract}

Kulcsszavak: újraélesztés, mentőtiszt, oktatás

\section{Adult advanced life support knowledge among ambulance officer/paramedic students in Hungary}

Introduction: Resuscitation knowledge is necessery for emergency care workers. Aim: The aim of the authors was to investigate the advanced life support knowledge of paramedic students in Hungary. Method: The research has been executed at University of Pécs - Faculty of Health Sciences, Semmelweis University - Faculty of Health Sciences, and University of Debrecen - Faculty of Health Care. 97 students $(n=97)$ were involved in the study from third and fourth grades. Data were recorded with a self-fill-in questionnaire. Results: Average scores were 67.79\%. There was no significant difference between women and men $(\mathrm{p}=0.725)$. Younger age improved significantly scores $(\mathrm{p}=0.003)$. Full-time students completed the test significantly better than part-time students $(\mathrm{p}=0.004)$. There was no significant difference between the students from different locations $(\mathrm{p}=0.254)$. Conclusions: It would be appropriate to increase the number of resuscitation courses and to tighten the exams. The authors propose that it would be reasonable to examine the students' practical skills.

Keywords: resuscitation, paramedic, education

Bánfai, B., Éliás, Á., Nagy, T., Pék, E., Betlehem, J. [Adult advanced life support knowledge among ambulance officer/paramedic students in Hungary]. Orv. Hetil., 2016, 157(37), 1476-1482.

(Beérkezett: 2016. június 13.; elfogadva: 2016. július 14.) 


\section{Rövidítések}

ALS = (advanced life support) kiterjesztett (emelt szintú) újraélesztés; BLS = (basic life support) alapszintú újraélesztés; $\mathrm{CPR}=$ (cardiopulmonary resuscitation $)$ szív-tüdő újraélesztés; ERC $=($ European Resuscitation Council $)$ Európai Újraélesztési Tanács; MRT = Magyar Resuscitatios Társaság

A hirtelen bekövetkező keringésleállások az egészségügyi ellátásban világszerte jelentős problémákat okoznak. Európában és az Amerikai Egyesült Államokban évente legalább 700000 ember halálát okozza a hirtelen szívhalál, amelyek esetén az újraélesztés sikertelen [1]. Az adatok alapján a fejlett országokban a hirtelen szívhalál a 3. leggyakoribb halálok, a daganatos megbetegedések és az egyéb szív- és érrendszeri megbetegedések után [2]. Magyarországon 2014-ben különböző szív- és érrendszeri megbetegedések (heveny szívizomelhalás, egyéb ischaemiás szívbetegség, agyérbetegség) összesen 44529 ember halálát okozták [3].

Ezekben az esetekben nagyon fontos, hogy minél elóbb megkezdődjön az újraélesztés. Mivel legtöbbször a rosszullét első észlelője laikus személy, így neki kellene megkezdeni a beteg ellátását. Ez azért jelentős, mert szakirodalmi adatok szerint ilyenkor, ha az ellátás nem kezdődik meg 3-5 percen belül, akkor egyértelmúen romlik a sikeres újraélesztés esélye, a maradandó egészségkárosodás valószínúsége pedig nő, ha az újraélesztés kimenetele sikeres is [4]. A késlekedés nélkül megkezdett segítségnyújtás a szakellátók feladatát is megkönnyíti. Magyarországon korábban fóként alapszintû́ újraélesztési ismeretekkel kapcsolatos felméréseket végeztek. Az egyik ilyen kutatásból az derült ki, hogy a megkérdezett ápolók több mint fele hiányosnak érzi újraélesztési ismereteit, éppen ezért szükségesnek tartanák a rendszeres továbbképzéseket [5]. Egy másik kutatásban 13 európai ország (köztük Magyarország) fiataljainak BLS-ismereteit hasonlították össze, amely során kiderült, hogy a nyugat-európai fiatalok és a korábbi képzésen átesettek magasabb ismereti szinttel rendelkeznek [6]. Egy indiai kutatásban orvostanhallgatók BLS-ismereteit mérték fel, ahol az eredmények azt mutatták, hogy az oktatást követő utómérés alkalmával (következő évben) mindössze a résztvevők 3\%-a volt képes a BLS összes lépését helyesen kivitelezni [7]. Más kutatások eredményei alapján azt állapították meg, hogy a BLS oktatása már általános és középiskolások számára is indokolt, hiszen ők is képesek elsajátítani a helyes kivitelezést $[8,9]$.

Viszont mindezek mellett fontos, hogy a szakellátók is a megfelelő ismeretekkel rendelkezzenek, hiszen ez nagymértékben befolyásolhatja az újraélesztés kimenetelét. Az ellátásra vonatkozóan szigorú protokoll áll rendelkezésünkre. Hazánkban a European Resuscitation Council (ERC) [10] és a Magyar Resuscitatios Társaság [11] aktuális irányelveit kell követnünk. (Ez ma a 2015. évi irányelv, viszont kutatásunk elvégzésekor még a 2010., illetve 2011. évi [12,13] volt érvényben.) Az ok- tatás módszere is nagy hatással van a megszerzett ismeretekre, amely során a gyakorlati résznek hangsúlyosnak kell lennie. Az American Heart Association (AHA) által végzett kutatásban kimutatták, hogy a legjobb eredmény akkor volt elérhető, amikor a hagyományos elméleti oktatást valósághú szimulációs gyakorlattal egészítették ki [14]. A Wik és mtsai által végzett kutatás azt mutatta ki, hogy az általuk vizsgált prehospitális szakellátók által végzett újraélesztés minősége elmarad az elvárt szinttől [15]. Abella és mtsai hospitális környezetben végzett kutatásukban hasonló eredményeket tapasztaltak [16].

Az említett ismeretek megszerzése az összes, sürgősségi ellátás területén dolgozó szakellátó számára elengedhetetlen. Jelen kutatásunk célja a magyar mentőtisztképzésben részt vevő harmad- és negyedéves hallgatók emelt szintû́ újraélesztéssel (ALS) kapcsolatos ismereteinek felmérése volt. Magyarországon 1975 óta folyik fóiskolai szintű mentőtisztképzés, jelenleg három intézményben: a Pécsi Tudományegyetem Egészségtudományi Karán (PTE-ETK), a Semmelweis Egyetem Egészségtudományi Karán (SE-ETK) és a Debreceni Egyetem Egészségügyi Karán (DE-EK) [17]. A képzési idő egységesen négy év, tehát nyolc szemeszter. A sürgősségi ellátásban a mentőtisztek elláthatnak feladatokat prehospitális és hospitális körülmények között is [18]. Előbbi esetben például az Országos Mentőszolgálatnál (OMSZ) kivonuló szolgálatot teljesítő szakember esetén egységvezetőként tevékenykedhetnek, míg utóbbi esetben például sürgősségi osztályon - a nem orvosi feladatot ellátó személyzetet erősítik.

Ezeket a tényezőket figyelembe véve gondoltuk fontosnak, hogy megvizsgáljuk, milyen ismeretekkel rendelkeznek a magyarországi mentőtiszthallgatók a hatályos újraélesztési irányelvekkel $[12,13]$ kapcsolatosan.

\section{Módszer}

Kutatásunk keresztmetszeti, kvantitatív jellegú vizsgálat volt. Adatfelvételi eszközként saját szerkesztésű, anonim, önkitöltős kérdő́ivet alkalmaztunk. Kérdőívünk összesen 35 kérdést tartalmazott, amelyek között volt 7 darab szociodemográfiai adatokra vonatkozó kérdés (nem, életkor, képzőhely, tagozat, iskolai végzettség, esetleges munkavégzéssel kapcsolatos adatok), valamint szakmai ismereteket vizsgáló kérdések. Utóbbiak esetében a kérdéseket négy kategóriába soroltuk: mellkaskompresszió, légútbiztosítás, lélegeztetés ( 6 kérdés); postresuscitatiós ellátás (5 kérdés); reverzibilis okok ismerete és kezelése (9 kérdés); sokkolandó, nem sokkolandó ritmuszavarok kezelése (8 kérdés). A szakmai ismeretek felmérésére minden esetben nyílt kérdéseket használtunk, ezek értékelésénél a European Resuscitation Council (ERC) 2010. évi [12] és a Magyar Resuscitatios Társaság (MRT) 2011. évi felnőtt emelt szintú újraélesztésre vonatkozó ajánlásokat [13] vettük figyelembe. A kérdőíveket az öszszes helyszínen kérdezőbiztosok töltették ki. A válaszok értékelése során a helyes válaszokért egységesen 1 pont 
járt, így a „mellkaskompresszió, légútbiztosítás, lélegeztetés” kérdéscsoportban maximum 30 pontot, a „postresuscitatiós ellátás" kérdéscsoportban maximum 15 pontot, a „reverzibilis okok ismerete és kezelése” kérdéscsoportban maximum 20 pontot, a „sokkolandó, nem sokkolandó ritmusok kezelése" kérdéscsoportban maximum 21 pontot szerezhettek a hallgatók. Az összpontszám 86 volt.

Az adatfelvétel 2014. május és november között zajlott. A vizsgálat helyszínei a Debreceni Egyetem Egészségügyi Kara (DE-EK), a Pécsi Tudományegyetem Egészségtudományi Kara (PTE-ETK, pécsi és szombathelyi képzési központ) és a Semmelweis Egyetem Egészségtudományi Kara (SE-ETK) voltak.

Kutatásunk célcsoportját a Magyarországon mentőtisztképzésben részt vevő intézmények harmad- és negyedéves hallgatói alkották. Beválasztási kritériumként azért szerepelt a harmadik és negyedik évfolyam látogatása, mert ekkorra érnek el a hallgatók a tanulmányaik során a felnőtt emelt szintú újraélesztés (ALS) elsajátításához. A vizsgálatban mindhárom, mentőtisztképzést szervező intézmény (DE-EK, PTE-ETK, SE-ETK) hallgatói részt vettek. A kiküldött 150 darab kérdőívből 125 darab érkezett vissza, amelyből 97 darab volt értékelhető, így mintánkat összesen 97 fő (n = 97) alkotta.

$\mathrm{Az}$ adatok rögzítését és elemzését Microsoft Excel 2010 és IBM SPSS 22 szoftverekkel végeztük. A minta jellemzése leíró statisztikai mutatókkal történt, a változók közötti összefüggések vizsgálatára pedig egyutas varianciaanalízist (One-Way ANOVA) és post hoc Tukeytesztet, független mintás t-próbát, $\chi^{2}$-próbát, valamint Pearson-féle korrelációanalízist alkalmaztunk. Az eredményeket 95\%-os konfidenciaintervallum mellett, $\mathrm{p}<0,05$ érték esetén tekintettük szignifikánsnak.

\section{Eredmények}

\section{Szociodemográfiai adatok}

A kutatásban részt vevő 97 fó $(\mathrm{n}=97)$ mentőtiszthallgató legfóbb szociodemográfiai adatait az 1 . táblázat mutatja be. A hallgatók átlagéletkora 24,45 \pm 5,070 év volt, a legfiatalabb 20 éves, a legidősebb 50 éves volt.

\section{Az egyes kategóriákban elért pontszámok}

A mellkaskompresszió, légútbiztosítás, lélegeztetés kérdéscsoportban a hallgatók a megszerezhető 30 pontból átlagosan 21,23 $\pm 3,087$ pontot $(70,76 \%)$ értek el. A leggyengébb eredmény 15 pont, a legjobb eredmény 29 pont volt.

A postresuscitatiós ellátás kérdéscsoportban a hallgatók a maximálisan elérhető 15 pontból átlagosan $9,78 \pm 3,008$ pontot $(65,22 \%)$ szereztek. A leggyengébb eredmény 4 pont, a legjobb eredmény 15 pont volt.

A reverzibilis okok ismerete és kezelése kérdéscsoportban a megszerezhető 20 pontból átlagosan 14,22 $\pm 2,976$
1. táblázat |A résztvevók jelentősebb szociodemográfiai adatai $(\mathrm{n}=97)$

\begin{tabular}{lll}
\hline Nem & Fő & $\%$ \\
\hline Férfi & 47 & 48,5 \\
Nő & 50 & 51,5 \\
\hline
\end{tabular}

\begin{tabular}{lll}
\hline Képzőhely & & \\
\hline DE-EK & 17 & 17,4 \\
PTE-ETK & 46 & 47,4 \\
SE-ETK & 34 & 35,1 \\
\hline
\end{tabular}

\begin{tabular}{lll}
\hline Tagozat & & \\
\hline Nappali & 71 & 73,2 \\
Levelező & 26 & 26,8 \\
\hline
\end{tabular}

\begin{tabular}{lcc}
\hline Legmagasabb iskolai végzettség & & \\
\hline Szakközépiskola/gimnázium & 91 & 93,8 \\
Főiskola/egyetem & 6 & 6,2 \\
\hline
\end{tabular}

\begin{tabular}{lcc}
\hline Munkaviszony (sürgősségi) & 33 & 34 \\
\hline Jelenleg aktív & 9 & 9,3 \\
Volt, de jelenleg nem aktív & 55 & 56,7 \\
Nincs (nem is volt) &
\end{tabular}

\begin{tabular}{lcc}
\hline Munkaviszony ideje & & \\
\hline Kevesebb mint 1 év & 12 & 12,4 \\
1-5 év & 17 & 17,5 \\
6-10 év & 10 & 10,3 \\
Több mint 10 év & 3 & 3,1
\end{tabular}

\begin{tabular}{lcc}
\hline ALS-tapasztalat (valódi) & & \\
\hline $1-10$ & 50 & 51,5 \\
$11-20$ & 22 & 22,7 \\
$21-30$ & 4 & 4,1 \\
30 feletti & 6 & 6,2
\end{tabular}

\begin{tabular}{lcc}
\hline Legutóbbi ALS-tapasztalat & & \\
\hline 2 hónapon belül & 38 & 39,2 \\
2-6 hónap között & 18 & 18,6 \\
7 hónap-1 év között & 17 & 17,5 \\
Több mint 1 éve & 9 & 9,3 \\
Nem volt & 15 & 15,5 \\
\hline
\end{tabular}

pontot $(71,08 \%)$ értek el a hallgatók. A leggyengébb eredmény 4 pont, a legjobb eredmény 20 pont volt.

A sokkolandó, nem sokkolandó ritmusok kezelése kérdéscsoportban a maximálisan elérhető 21 pontból átlagosan $13,07 \pm 2,587$ pontot $(62,25 \%)$ értek el az alanyok. Itt a leggyengébb eredmény 5 pont, a legjobb 18 pont volt.

A teszten maximálisan elérhető összpontszám 86 volt. A hallgatók átlagosan $58,30 \pm 7,472$ pontot $(67,79 \%)$ szereztek. A leggyengébb teljesítmény 37 pont, a legjobb 71 pont volt. 


\section{Összefüggések vizsgálata az eredmények alapján}

Összehasonlítva a női $(58,56 \pm 7,646)$ és férfi $(58,02 \pm 7,356)$ hallgatók összesített elért eredményeit, az látható, hogy a két nem között nem volt szignifikáns különbség $(\mathrm{F}=0,125 ; \mathrm{p}=0,725)$.

$\mathrm{Az}$ elért eredményeket a hallgatók életkorával összefüggésben vizsgálva megállapítható, hogy a postresuscitatiós kérdéscsoportban $(\mathrm{r}=-0,211 ; \mathrm{p}=0,038)$, a reverzibilis okok ismerete és kezelése kérdéscsoportban $(\mathrm{r}=-0,356 ; \mathrm{p}<0,05)$, a sokkolandó, nem sokkolandó ritmusok kezelése kérdéscsoportban $(\mathrm{r}=-0,388$; $\mathrm{p}=0,001)$, illetve az összpontszám tekintetében is $(\mathrm{r}=-0,295 ; \mathrm{p}=0,003)$, az életkor csökkenésével szignifikánsan emelkedtek a résztvevók által megszerzett pontszámok.

A nappali és levelező tagozatos hallgatók eredményeit összehasonlítva az látható, hogy a nappali munkarendú hallgatók a sokkolandó, nem sokkolandó ritmusok kezelése kérdéscsoportban $(\mathrm{F}=9,840 ; \mathrm{p}=0,02)$, a reverzibilis okok ismerete és kezelése $(\mathrm{F}=17,877 ; \mathrm{p}<0,05)$, valamint az összesített pontszámot tekintve szignifikánsan jobban teljesítettek $(\mathrm{F}=8,549 ; \mathrm{p}=0,004)$.

A képző intézmény tekintetében az összpontszámokat vizsgálva megállapítható, hogy nem volt szignifikáns különbség az eredmények között $(\mathrm{F}=1,390 ; \mathrm{p}=0,254)$.

Vizsgáltuk, hogy van-e összefüggés az egyes kérdéscsoportokban elért pontszámok, valamint a teszten elért összpontszámok között a sürgősségi munkaviszony ténye, illetve minősége szerint. Az eredmények tükrében megállapítható, hogy sem az egyes kérdéscsoportokra adott válaszok, sem az összpontszám tekintetében nem volt szignifikáns a különbség $(\mathrm{F}=0,275 ; \mathrm{p}=0,760)$. Ebben a tekintetben vizsgáltuk azt is, hogy van-e összefüggés a defibrilláció során választandó energiaértékek és a munkaviszony megléte között. A kapott eredmények szerint, azon hallgatók közül, akiknek nincs sürgősségi ellátáson belül munkaviszonya, 32 fó $(58,2 \%)$ adott meg helyes értéket. A sürgősségi munkaviszonnyal rendelkezô csoport tagjai közül 14 fó $(42,4 \%)$ adott helyes értéket. Azon hallgatóknál, akiknek korábban volt munkaviszonya, ez a szám 3 fó $(33,3 \%)$ volt. A változók között szignifikáns összefüggést nem találtunk $(\mathrm{p}=0,383)$. Összességében vizsgálva a résztvevő́k eredményét, az látható, hogy a kitöltők közül 49 fó $(50,5 \%)$ adott helyes választ erre a kérdésre.

Azok a hallgatók, akik korábban vettek részt valós újraélesztési szituációban, a mellkaskompresszió, légútbiztosítás, lélegeztetés kérdéscsoportnál $(\mathrm{F}=8,223 ; \mathrm{p}=$ $0,005)$, illetve az összpontszámot tekintve szignifikánsan jobban teljesítettek $(\mathrm{p}=0,009)$. Vizsgáltuk a lehetséges összefüggést a valós újraélesztésen való részvételek számával összefüggésben. A teszten elért összpontszám tekintetében az 1-10 újraélesztésen részt vett csoport átlagosan $58,38 \pm 6,77$ pontot, a $11-20$ újraélesztésen részt vett csoport átlagosan $60,09 \pm 7,270$ pontot, a $21-30$ újraélesztésen részt vett csoport átlagosan 60,50 \pm 6,557 pontot, a 30 feletti újraélesztésen részt vett csoport átlagosan $61 \pm 6,663$ pontot, akik pedig nem vettek részt, átlagosan 53,73 $\pm 9,996$ pontot szereztek. A tapasztalattal nem rendelkező csoport tagjai szignifikánsan gyengébben teljesítettek az $1-10$ csoport tagjainál $(\mathrm{p}=0,037)$ és a 11-20 csoport tagjainál $(\mathrm{p}=0,031)$, de eredményeik nem tértek el szignifikánsan a 21-30 csoport tagjainak eredményétôl $(\mathrm{p}=0,147)$ és a $30+$ csoport tagjainak eredményétól $(\mathrm{p}=0,072)$. Az $1-10$ csoport tagjainak eredménye nem tért el szignifikánsan a 11-20 csoport tagjainak $(\mathrm{p}=0,348)$, a $2 \mathrm{l}-30$ csoport tagjainak $(\mathrm{p}=$ $0,572)$ és a $30+$ csoport tagjainak eredményétól $(\mathrm{p}=$ $0,394)$. A 11-20 csoport tagjainak eredménye nem tért el szignifikánsan a $21-30$ csoport tagjainak $(\mathrm{p}=0,915)$ és a $30+$ csoport tagjainak eredményétől $(\mathrm{p}=0,778)$. A 21-30 csoport és a 30+ csoport tagjainak eredménye közt nem volt szignifikáns összefüggés $(p=0,910)$. A korábbi valós szituáció idejét tekintve azt az eredményt kaptuk, hogy azon hallgatók, akik a felmérést megelőző 2 hónapon belül vettek részt valós újraélesztésben, szignifikánsan jobban teljesítettek, mint akik korábban nem vettek részt ilyen ellátásban $(\mathrm{p}=0,013)$. A többi csoportba tartozó (2-6 hónap, 7 hónap-1 év, 1 évnél régebb) hallgatók eredményei nem mutattak szignifikáns összefüggést.

Korrelációanalízist alkalmazva megvizsgáltuk az egyes kérdéscsoportokban elért eredmények közti kapcsolatot valamennyi lehetséges kombinációban. A hallgatók által a kérdéscsoportokban megszerzett átlagpontszámok és az elvégzett statisztikai próba eredményei a 2. táblázatban láthatók. $\mathrm{Az}$ eredmények azt mutatták, hogy a postresuscitatiós ellátás kérdéscsoportban, a reverzibilis okok ismerete és kezelése kérdéscsoportban és a sokkolandó, nem sokkolandó ritmusok kezelése kérdéscsoportban elért eredmények egymással statisztikai összefüggésben álltak (minden esetben $\mathrm{p}<0,05$ ). A mellkaskompresszió, légútbiztosítás, lélegeztetés kérdéscsoport eredménye és a többi kérdéscsoport eredményei között szignifikáns összefüggést nem találtunk.

\section{További lényeges eredmények}

Az egyes kérdéscsoportokból néhány kérdésre adott választ egyenként is érdemesnek találtuk megvizsgálni. Ilyen volt például a postresuscitatiós ellátás során szükséges kilégzésvégi $\mathrm{CO}_{2}$-szint $\left(\mathrm{ETCO}_{2}\right)$ célértéke. A mintánk $59,8 \%$-a adott helyes választ erre a kérdésre.

A hypothermiás (a kérdés alapján $28{ }^{\circ} \mathrm{C}$-os maghőmérsékletü) beteg gyógyszerelésével kapcsolatos kérdésre 65 fó $(67 \%)$ adott helyes választ.

A kérdőívünkben három EKG-ritmus is szerepelt, amelyeket a kitöltóknek fel kellett ismerni. Az elsőt (torsade de pointes típusú kamrai tachycardia) a résztvevők 87,6\%-a, a másodikat (kamrai tachycardia) 78,4\%-a, míg a harmadikat (pulzus nélküli elektromos aktivitás - PEA) $72,2 \%$-a ismerte fel helyesen. 


\begin{tabular}{|c|c|c|c|c|c|}
\hline & & $\begin{array}{l}\text { Mellkaskompresszió, } \\
\text { légútbiztosítás, } \\
\text { lélegeztetés }\end{array}$ & $\begin{array}{l}\text { Postresuscitatiós } \\
\text { ellátás }\end{array}$ & $\begin{array}{l}\text { Reverzibilis okok } \\
\text { ismerete és kezelése }\end{array}$ & $\begin{array}{l}\text { Sokkolandó, nem } \\
\text { sokkolandó ritmusok } \\
\text { kezelése }\end{array}$ \\
\hline \multirow{2}{*}{$\begin{array}{l}\text { Mellkaskompresszió, } \\
\text { légútbiztosítás, } \\
\text { lélegeztetés }\end{array}$} & Korrelációs együttható (r) & 1,000 & $-0,045$ & $-0,084$ & $-0,100$ \\
\hline & Szignifikanciaszint $(\mathrm{p})$ & - & 0,661 & 0,415 & 0,330 \\
\hline \multirow[t]{2}{*}{ Postresuscitatiós ellátás } & Korrelációs együttható (r) & $-0,045$ & 1,000 & 0,489 * & $0,456^{*}$ \\
\hline & Szignifikanciaszint $(\mathrm{p})$ & 0,661 & - & $<0,05^{*}$ & $<0,05^{*}$ \\
\hline \multirow{2}{*}{$\begin{array}{l}\text { Reverzibilis okok } \\
\text { ismerete és kezelése }\end{array}$} & Korrelációs együttható (r) & $-0,084$ & 0,489 * & 1,000 & $0,456^{*}$ \\
\hline & Szignifikanciaszint $(\mathrm{p})$ & 0,415 & $<0,05$ * & - & $<0,05^{*}$ \\
\hline \multirow{2}{*}{$\begin{array}{l}\text { Sokkolandó, nem } \\
\text { sokkolandó ritmusok } \\
\text { kezelése }\end{array}$} & Korrelációs együttható (r) & $-0,100$ & $0,456^{*}$ & $0,638^{*}$ & 1,000 \\
\hline & Szignifikanciaszint $(\mathrm{p})$ & 0,330 & $<0,05^{*}$ & $<0,05^{*}$ & - \\
\hline
\end{tabular}

*Csillag jelzéssel a kérdéscsoportok közötti szignifikáns kapcsolatokat jelöltük.

\section{Megbeszélés}

Kutatásunkban magyarországi képzőintézményekben tanulmányokat folytató harmad- és negyedéves mentőtiszthallgatókat mértünk fel, amelynek során felnőtt emelt szintű újraélesztéssel kapcsolatos ismereteiket vizsgáltuk. A szakirodalom áttekintésekor nem találtunk pontosan ezzel a témával foglalkozó korábbi kutatást.

A kérdőív kitöltével a hallgatók a maximálisan elérhető 86 pontból átlagosan $58,30 \pm 7,472$ pontot $(67,79 \%)$ szereztek. Ez az eredmény nem nevezhető jónak, hiszen újraélesztés során kifejezett jelentősége van annak, hogy a szükséges beavatkozásokat szakszerúen és pontosan hajtsuk végre. Ezt segítendő a korábbi szakmai tapasztalatokat magába foglaló protokoll is rendelkezésre áll [10, 11].

A férfi és női hallgatók eredményeinek összehasonlításakor nem találtunk eltérést a két nem ismeretei között. A résztvevők életkora és az elért eredmény között viszont szignifikáns volt az összefüggés: a fiatalabb hallgatók jobb eredményt értek el, mint az idősebbek. Ezzel összefüggésben állhat az az eredményünk is, miszerint a kitöltők közül a nappali tagozatos hallgatók teljesítettek jobban. Ezt alátámaszthatja az a tény, hogy a levelező munkarendű hallgatók átlagéletkora magasabb, valamint azzal is összefüggésben állhat, hogy a levelező munkarend képzésében az egyes félévek során nem rendszeres az elméleti oktatás, hanem havonta tömbösített órák keretében történik az ismeretek átadása.

Kapott eredményeink alapján az a tény, hogy az adott hallgató dolgozik-e a sürgősségi ellátás területén, nem befolyásolta az adott válaszokat. Egy szisztematikus áttekintés adatai szerint korábbi kutatásokban részt vevő szakemberek esetében pozitív befolyásoló ereje volt, ha valaki gyakorlati munkát végzett az adott területen [19]. Viszont azoknak a hallgatóknak az összpontszáma esetünkben is magasabbnak bizonyult, akik korábban vettek részt valós újraélesztési szituációban (munka vagy szak- mai gyakorlat során). Ehhez hasonló következtetésre jutottak egy korábbi kutatásban, ahol azt az eredményt kapták, hogy azok az ápolóhallgatók, akik elméleti és gyakorlati ALS-oktatáson is részt vettek, jobban teljesítettek azoknál, akik csak elméleti oktatáson vettek részt [20]. Esetünkben ennél a kérdésnél viszont nem mondható ki egyértelmúen, hogy minél több valós szituációban vett részt a hallgató, annál magasabb pontszámot ért el. A korábbi tapasztalat időpontját vizsgálva az látható, hogy akiknél ez a kitöltést megelőző két hónapon belül történt, szignifikánsan jobban teljesítettek, viszont a többi esetben nem volt befolyással a kapott eredményekre. Egy görög kutatásban ápolók és orvosok BLS- és ALS-ismereteit mérték fel, ahol azt az eredményt kapták, hogy sok a szakemberek tudásbeli hiányossága. Viszont az is látható volt, hogy azok az ellátók, akik az elmúlt egy évben legalább 5 újraélesztésben részt vettek, szignifikánsan jobban teljesítettek a felmérés során [21].

\section{Észrevételek egyéb eredményeinkkel kapcsolatban}

Vizsgáltuk a lehetséges kapcsolatot a defibrilláció során választott energiaérték és a sürgősségi ellátásban meglévő munkaviszony ténye között. A résztvevők közül mindössze 49 fó $(50,5 \%)$ válaszolt helyesen erre a kérdésre, amely nagyon csekély szám. Egy korábbi pakisztáni kutatás során sürgősségi osztályon dolgozó orvosok körében is vizsgálták ezt a kérdést, ott még rosszabb eredmények születtek, hiszen a résztvevők mindössze 25,7\%-a válaszolt helyesen [22]. Ez azért fontos, mert egyértelmúen kimutatták, hogy sokkolandó ritmus esetén a korai defibrilláció nagymértékben képes növelni a túlélési esélyeket $[23,24]$. Ehhez viszont szükséges, hogy a szakemberek képesek legyenek ezt helyesen kivitelezni. A kapott eredmények szerint azon hallgatók közül, akiknek nincs sürgôsségi ellátáson belül munkaviszonya, 32 fó $(58,2 \%)$ adott meg helyes értéket. A sürgősségi munkaviszonnyal rendelkező csoport tagjai 
közül 14 fő $(42,4 \%)$ adott helyes értéket. Azoknál a hallgatóknál, akiknek korábban volt munkaviszonya, ez a szám 3 fó $(33,3 \%)$ volt. A változók között szignifikáns összefüggést nem találtunk ( $\mathrm{p}=0,383)$.

A kilégzésvégi $\mathrm{CO}_{2}\left(\mathrm{ETCO}_{2}\right)$-érték mérése és értékelése egyre nagyobb szerepet játszik az újraélesztés folyamatában $[9,10,25,26]$. A kapott adat felhasználható a mellkaskompressziók minőségének értékelésére, a tubuspozíció megerősítésére, valamint sikeres újraélesztést követően (RoSC) prognosztikai értékkel is bír. Emiatt tartottuk fontosnak felmérni, hogy a hallgatók tisztában vannak-e utóbbi esetben az ETCO ${ }_{2}$ célértékével. A megkérdezettek mindössze kicsit több mint fele $(59,8 \%)$ válaszolt helyesen erre a kérdésre.

Keringésmegállás esetén az EKG-ritmus helyes felismerése fontos feladat, hiszen ez nagymértékben meghatározza a további teendőket. A kérdőívünkben szereplő három EKG-ritmus közül az elsőt a résztvevők 87,6\%-a, a másodikat 78,4\%-a, míg a harmadikat 72,2\%-a ismerte fel helyesen, tehát az eredmények alapján a hallgatók körülbelül háromnegyede találta el a helyes diagnózist.

\section{Következtetések}

Tekintettel arra, hogy a végzett mentőtisztek - ahogy más sürgősségi ellátás területén dolgozó szakemberek munkavégzésének minőségén szó szerint emberéletek múlnak, így a kutatásunkban részt vevő mentőtiszthallgatók emelt szintű újraélesztéssel kapcsolatos ismereteinek szintje nem tekinthető kielégítőnek. Viszont figyelembe kell venni, hogy ezek a hallgatók még a képzési rendszerben vannak, így van lehetőség a felmerülő hiányosságok pótlására, mielőtt oklevelet szereznek és megkezdik munkájukat mentőtisztként. Az általunk feltett kérdések csak elméleti ismeretekre vonatkoztak, viszont ezek megléte elengedhetetlen ahhoz, hogy az adott ellátó gyakorlatban képes legyen helyesen kivitelezni az ellátást. A kapott eredmények hátterében állhatnak az oktatási rendszerból adódó hiányosságok (például nem elég szigorú vizsgarendszer), vagy személyes tényezők is (például nem megfelelő szintû elhivatottság, nem megfelelő felkészülés). Az említett problémák felismerése és korrigálása azért fontos, hogy a képzés végeztével olyan szakemberek állhassanak munkába, akik ténylegesen rendelkeznek a szakszerü ellátáshoz szükséges ismeretekkel.

\section{A kutatás korlátai}

Vizsgálatunk kizárólag elméleti ismeretek mérésére irányult. A felnőtt emelt szintű újraélesztés szakszerü elvégzéséhez a mentőtiszteknek (és más egészségügyi szakembereknek) gyakorlatban kell alkalmazniuk az elsajátított ismereteket. A gyakorlati készségek felmérése során elképzelhető, hogy az elméleti méréshez képest jelentősen eltérő eredményeket kapnánk. Ennek tükrében indikáltnak tartanánk egy olyan, magyarországi mentőtiszthallgatók körében szervezett kutatást, amely az el- méleti ismeretek és gyakorlati készségek vizsgálatát is magába foglalja.

Kutatásunkban nem szerepelt a felsőoktatási képzés mellett egyéb ALS-tanfolyamokon, ALS témájú munkahelyi továbbképzéseken történt részvétel tényét vizsgáló kérdés, így a mintába bekerülhetett olyan hallgató is, akinek az elért eredményére hatással lehettek az említett képzések.

Kutatásunk során nem tértünk ki a mentőtisztképzést szervező intézményekben alkalmazott oktatási módszerek vizsgálatára, a hallgatók által az előadásokon történő részvétel valós idejének, arányának a felmérésére. Ezeknek a tényezőknek a megléte, különbözősége is befolyással lehet a hallgatói teljesítményekre.

Anyagi támogatás: Jelen kutatás és a kézirat elkészítése anyagi támogatásban nem részesült.

Szerzői munkamegosztás: B. B.: A kutatási eszköz (kérdőiv) véleményezése, részvétel a statisztikai elemzés elvégzésében, a kézirat és az angol nyelvű összefoglaló elkészítése. É. Á.: A kutatási eszköz (kérdőív) kidolgozása, adatfelvétel, adatbázis létrehozása, statisztikai elemzés. N. T.: Részvétel a kutatási eszköz (kérdőív) kidolgozásában, statisztikai elemzés. P. E.: Stilisztikai, nyelvhelyességi áttekintés, korrigálás. B. J.: A kutatás módszertani szakértői feladatainak ellátása, a vizsgálat irányítása. A kézirat végleges változatát valamennyi szerző elolvasta és jóváhagyta.

Érdekeltségek: A szerzőknek nincsenek érdekeltségeik.

\section{Irodalom}

[1] Nichols, M., Townsend, N., Luengo-Fernandez, R., et al.: European Cardiovascular Disease Statistics 2012. European Heart Network, Brussels, European Society of Cardiology, Sophia Antipolis, 2012.

[2] Berdowski, J., Berg, R. A., Tijssen, J. G., et al.: Global incidences of out-of-hospital cardiac arrest and survival rates: systematic review of 67 prospective studies. Resuscitation, 2010, 81, 14791487.

[3] Yearbook of Health Statistics, 2014. [Egészségügyi Statisztikai Évkönyv, 2014.] Központi Statisztikai Hivatal, 2015. [Hungarian]

[4] Taccone, F. S., Crippa, I. A., Dell'Anna, A. M., et al.: Neuroprotective strategies and neuroprognostication after cardiac arrest. Best Pract. Res. Clin. Anaesthesiol., 2015, 29(4), 451-464.

[5] Hódosi, B.: Nurse perspective of resuscitation education. [Az újraélesztés és oktatása diplomás ápolói szemmel.] Nővér, 2004, 17(4), 8-18. [Hungarian]

[6] Marton, J., Pandúr, A., Pék, E., et al.: Knowledge about basic life support in European students. [Európai fiatalok alapszintű életmentési ismeretei.] Orv. Hetil., 2014, 155(21), 833-837. [Hungarian]

[7] Pande, S., Pande, S., Parate, V., et al.: Evaluation of retention of knowledge and skills imparted to first-year medical students through basic life support training. Adv. Physiol. Educ., 2014, $38(1), 42-45$.

[8] Meissner, T. M., Kloppe, C., Hanefeld, C.: Basic life support skills of high school students before and after cardiopulmonary resus- 
citation training: a longitudinal investigation. Scand. J. Trauma Resusc. Emerg. Med., 2012, 20, 31.

[9] Jones, I., Whitfield, R., Colquboun, M., et al.: At what age can schoolchildren provide effective chest compressions? An observational study from the Heartstart UK schools training programme. BMJ, 2007, 334(7605), 1201.

[10] Soar, J., Nolan, J. P., Böttiger, B. W., et al.: European Resuscitation Council Guidelines for Resuscitation 2015. Section 3. Adult advanced life support. Resuscitation, 2015, 95, 100-147.

[11] http://www.reanimatio.com/sites/reanim_hu/media/files/ ERC_MRT_Ujraelesztes_Ajanlas_2015_10_14_v5.pdf [Hungarian]

[12] Deakin, C. D., Nolan, J. P., Soar, J., et al.: European Resuscitation Council Guidelines for Resuscitation 2010. Section 4. Adult advanced life support. Resuscitation, 2010, 81(10), 1305-1352.

[13] http://www.reanimatio.com/downloads/2011_als_mrt.pdf [Hungarian]

[14] Davis, L. E., Storjohann, T. D., Spiegel, J. J., et al.: High-fidelity simulation for advanced cardiac life support training. Am. J. Pharm. Educ., 2013, 77(3), 59

[15] Wik, L., Kramer-Johansen, J., Myklebust, H., et al.: Quality of cardiopulmonary resuscitation during out-of-hospital cardiac arrest. JAMA, 2005, 293(3), 299-304.

[16] Abella, B. S., Alvarado, J. P., Myklebust, H., et al.: Quality of cardiopulmonary resuscitation during in-hospital cardiac arrest. JAMA, 2005, 293(3), 305-310.

[17] Debródi, G.: Development of emergency care. In: Debrődi, G.: History of emergency care in Hungary, 1769-2012. [A mentéstudomány és fejlődése. In: Debrődi, G.: A magyarországi mentésügy története, 1769-2012.] Magyar Oxiológiai Társaság, Budapest, 2012. [Hungarian]

[18] Betlehem, J., Pék, E.: International dimensions in educational challanges of emergency medical service. [A sürgősségi egészségügyi ellátás képzési kihívásai nemzetközi dimenzióban.] Magyar Mentésügy, 2015, 29(1), 6-12. [Hungarian]
[19] Yang, C. W., Yen, Z. S., McGowan, J. E., et al.: A systematic review of retention of adult advanced life support knowledge and skills in healthcare providers. Resuscitation, 2012, 83(9), 1055-1060.

[20] Tawalbeh, L. I., Tubaishat, A.: Effect of simulation on knowledge of advanced cardiac life support, knowledge retention, and confidence of nursing students in Jordan. J. Nurs. Educ., 2014, 53(1), 38-44.

[21] Passali, C., Pantazopoulos, I., Dontas, I., et al.: Evaluation of nurses' and doctors' knowledge of basic and advanced life support resuscitation guidelines. Nurse Educ. Pract., 2011, $11(6)$, 365-369.

[22] Amin, S. M., Rafi, A., Atique, R., et al.: Knowledge of advanced cardiac life support in doctors concerned with emergency medical services. Ann. Hamd. Uni., 2010, 1(1), 38-40.

[23] Gong, ., Lu, ., Zhang, L., et al.: Predict defibrillation outcome using stepping increment of poincare plot for out-of-hospital ventricular fibrillation cardiac arrest. BioMed Res. Int., 2015, 2015, Article ID 493472.

[24] Infinger, A. E., Vandeventer, S., Studnek, J. R.: Introduction of performance coaching during cardiopulmonary resuscitation improves compression depth and time to defibrillation in out-ofhospital cardiac arrest. Resuscitation, 2014, 85(12), 1752-1758.

[25] Turle, S., Sherren, P. B., Nicholson, S., et al.: Availability and use of capnography for in-hospital cardiac arrests in the United Kingdom. Resuscitation, 2015, 94, 80-84.

[26] Murphy, R. A., Bobrow, B. J., Spaite, D. W., et al.: Association between prehospital CPR quality and end-tidal carbon dioxide levels in out-of-hospital cardiac arrest. Prehosp. Emerg. Care, 2016, 20(3), 369-377.

(Bánfai Bálint,

Pécs, Vörösmarty u. 4., 7621 e-mail: balint.banfai@etk.pte.hu

\section{A rendezvények és kongresszusok híranyagának leadása}

a lap megjelenése előtt legalább 40 nappal lehetséges, a 6 hetes nyomdai átfutás miatt. Kérjük megrendelőink szíves megértését.

A híranyagokat a következö címre kérjük: Orvosi Hetilap titkársága: Budai.Edit@akkrt.hu Akadémiai Kiadó Zrt. 